\title{
Primary signet-ring cell adenocarcinoma of the urinary bladder: A case report
}

\author{
M. Cobo-Dols, J. Alcaide, V. Gutiérrez, S. Gil, I. Alés, E. Villar, A. Montesa, F. Carabantes,
} J. J. Bretón, M. Benavides

\section{Summary}

Primary signet-ring cell adenocarcinoma of the urinary bladder is a rare tumor. We report in this study the case of a 53 year old man consulting for gross hematuria. Computed tomography imaging demonstrated right hydronephrosis and an invasive bladder tumor. The bladder biopsy showed a signetring cell carcinoma; the exploration of the gastrointestinal tract did nor reveal any other tumor localization. A total cystoprostatectomy was performed followed by adjuvant chemotherapy with cisplatin and gemcitabine. The aim of this study is to determine the anatomoclinical, therapeutic and evolutionary characteristics of this rare tumor.

Key words: Signet-ring cell. Urinary bladder. Adenocarcinoma. Chemotherapy.

Oncología, 2006; 29 (4):177-180

\section{Resumen}

El adenocarcinoma de células en anillo de sello primario de vejiga es un tumor raro. Describimos un caso de un varón de 53 años que consultó por hematuria macroscópica. La imagen de la tomografía axial computerizada mostró un hidronefrosis derecha y un tumor invasivo de la vejiga urinaria. La biopsia mostró un carcinoma de células en anillo de sello. No se detectó localización primaria digestiva en la exploración del tracto grastrointestinal. El paciente se trató con cistoprostatectomía total y quimioterapia adyuvante con cisplatino y gemcitabina. El objetivo de este caso es presentar las características anatomoclínicas, tratamiento y evolución de este infrecuente tumor.

Palabras clave: Células en anillo de sello. Vejiga urinaria. Adenocarcinoma. Quimioterapia. 


\section{Introduction}

Primary signet ring cell carcinoma (PSRCC) of the urinary bladder is a rare variant of mucusproducing adenocarcinoma, which was first reported by Saphir ${ }^{1}$. We report this case of PSRCC treated with total cystectomy and adjuvant chemotherapy .

\section{Case report}

A 53-year-old man was admitted to the hospital with the complaint of gross hematuria of 1 month. Ultrasonography revealed grade II right hydronephrosis. A partial defect on the right bladder wall was found on intravenous urography. Computed tomography imaging demonstrated right hydronephrosis and an invasive bladder tumour but no distant metastasis was detected. Cystoscopy revealed a white, sessile tumour extending from the right bladder wall to the trigone and incompletely obstructing the right ureteral orifice. Tissues were taken by punch and hot loop resection. Histologic examination revealed a predominance of cancer cells forming abundant mucin with positive staining of the cytoplasm by periodic acid-Schiff (Fig. 1). A component of transitional cell carcinoma was not found in the biopsy specimens. After this histologic report, gastrointestinal radiographic studies, esophagogastroduodenalendoscopy, and rectosigmoidoscopy were performed to exclude other possible extravesical primary lesions. Finally, we diagnosed a PSRCC of the uri-

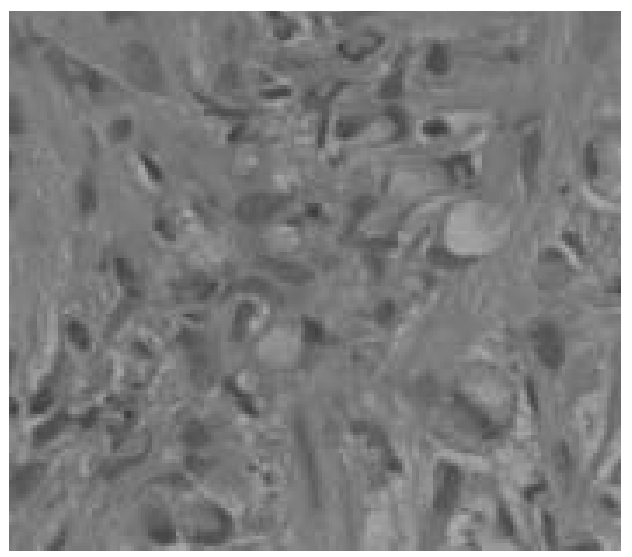

Figure 1. Microscopic findings of signet ring cell carcinoma. Histologic examination revealed a predominance of cancer cells forming abundant mucin. nary bladder and patient underwent total cystectomy and urinary diversion.

The surgical specimen consisted of the resected urinary bladder, prostate, urethra and pelvic lymph nodes. Grossly, the tumour extended from the trigone to the right wall. Microscopically, the bladder wall showed diffuse infiltration of tumour cells, consisting of signet-ring cells that had invaded the deeper layers of the bladder invading prostate and no metastasized to the pelvic lymph nodes (Grade 3, pT4a, pN0, pM0). Adjuvant chemotherapy was performed after consent of the patient, with four cycles with the combination of cisplatin $100 \mathrm{mg} / \mathrm{m}^{2}$ day $1^{\circ}$ and gemcitabine $1000 \mathrm{mg} / \mathrm{m}^{2}$ days $1^{\circ}$ and $8^{\circ}$, every 21 days. After 8 months completing all treatment, patient was free of local and systemic relapse.

\section{Discussion}

Primary adenocarcinoma of the urinary bladder comprises $0,5-2 \%$ of all primary bladder carcinoma. It is believed that theses tumours result from metaplastic changes of potentially unestable urothelium. Many investigators proposed that the metaplastic potential of the urothellium has two distinct patters. Progressive invagination of hyperplastic epithelial buds into the lamina propia (Von Brunn's nest) leads to the formation of cystitis cystica. Subsequent, metaplasia of the urothelial lining to these cyst to columnar mucin-producing cells results in the production of cystitis glandularis, which is premalignant lesion ${ }^{2}$. Alternatıvely, cuboidal or columnar metaplasia of the surface epithelium can occur with no downward invagination, Chronic vesical irritation and infection are the predisposing factors of theses changes. This explains, at least partly, the higher incidence of these tumours among patients with bilharzial cystitis. Most of these tumours are mucin-secreting but the passage of mucus during micturition is uncommon. In the vast of series, twothirds of the tumours were mucin-secreting, in most of which the site of deposition was extracelular (interstitial $)^{2,3}$. Less commonly, mucin is secreted within the lumen of the acini and infrequently, excessive intracellular mucin displaces the nucleus to a peripheral crescent, giving the cells a signet-ring appearance. It is generally believed that this variety has a poor prognosis ${ }^{4}$. 
Signet-ring cell carcinoma, a relative rare neoplasm that mostly arises in the stomach, colon, breast or glallblader, and rarely in the urinary bladder (PSRCC), has been reported in more than 70 patients appearing in the English medical reports ${ }^{5,6}$, and 40 cases in the Japanese medical reports ${ }^{7}$ since Saphir et al reported the first two cases in $1955^{1}$. Grignon et $\mathrm{al}^{5}$ suggested that the criteria for diagnosis of PSRCC should be restrictive. According to their criteria, the presence of individual signet ring cells permeating the bladder wall in linitis plastica fashion is necessary for the diagnosis. In addition, cases in which a transitional cell component is associated with signet ring cell carcinoma should be excluded, because transitional cell components are frequently identified by routine mucin staining and may confuse the diagnosis ${ }^{8}$. On the basis of their criteria, the present case should be diagnosed as adenocarcinoma of the urinary bladder with signet ring cell features without mixed transitional cell carcinoma. However, the histogenesis of PSRCC of the bladder has not been clarified. Three possibilities for the histogenesis have been considered ${ }^{8-11}$. The first possible origin is the metaplastic potential of urothelium, and most adenocarcinomas arise in this fashion ${ }^{8-10}$. A second possibility is that diffuse signet ring cell adenocarcinoma arises from isolated signet ring cells that exist in normal transitional cell epithelium, since such individual mucin-secreting cells were found scattered in nonneoplastic transitional epithelium ${ }^{8,10}$. A third possible origin is signet ring cell carcinoma arising from metaplastic transitional cell carcinoma, since areas of transitional cell carcinoma were mixed with signet ring cell carcinoma in some reported.

A review of previous reports revealed the prognosis of PSRCC to be poor, because silent progression of this cancer leads to a delay in diagnosis ${ }^{6}$. At the time of diagnosis, most patients have reached a high stage of disease ${ }^{6,8}$. According to the review by Erdogru et $\mathrm{al}^{6}$ surgical procedures, as well as chemotherapy and radiotherapy, are generally unsuccessful. They reported that only total cystectomy might offer some hope for patients ${ }^{6}$. Unfortunately, no standard chemotherapy exists for PSRCCs of the bladder because of their rarity. The effects of chemotherapy on signet ring cell carcinoma arising from other organs provide limited information, because PSRCC of the urinary bladder may have cha- racteristics differing from those of such tumors. Ota el $\mathrm{al}^{12}$ reported effective treatment with intra-arterial chemotherapy with cisplatin and metotrexato and radiation therapy. Tanaka el $\mathrm{al}^{13}$ also reported effective treatment with systemic chemotherapy and radiation therapy. Other authors have treated this tumours with radiotherapy after cystectomy ${ }^{14}$. We report this case of PSRCC treated successfully with total cystectomy followed by systemic chemotherapy with cisplatin and gemcitabine, a standard combination for transitional carcinoma of the urinary bladder.

\author{
Correspondence: \\ Manuel Cobo-Dols, MD \\ Sección de Oncología Médica \\ Pabellón A, $3^{\circ}$ planta derecha \\ Secretaría de Oncología Médica \\ Hospital Regional Universitario Carlos Haya \\ Avda. Carlos Haya, s/n \\ E-29010 Málaga (España) \\ manuelcobodols@yahoo.es \\ mangel.cobo.sspa@juntadeandalucia.es
}




\section{References}

1. Saphir O. Signet ring cell carcinoma of the bladder. Am J Pathol 1955;31: 223-231.

2. El-Mekresh MM, El-Baz MA, Abol-Enein H, et al. Primary adenocarcinoma of the urinary bladder: a report of 185 cases. British J Urol 1998;82:206-212.

3. Thomas DG, Ward AM, and Williams JL. A study of 52 cases of adenocarcinoma of the bladder. Br J Urol 1971; 43: 4-15.

4. Blute ML, Engen DE, Treavis WD, et al. Primary signet ring cell adenocarcinoma of the bladder. J Urol 1989;141: 17-21.

5. Grignon JD, Ro JY, Ayala AG, et al. Primary signet-ring cell carcinoma of the urinary bladder. Am J Clin Pathol 1991;95:13-20.

6. Erdogru T, Kiligaslan I, Esen T, et al. Primary signet ring cell carcinoma of the urinary bladder: review of the literature and report of two cases. Urol Int 1995; 55: 34-37.

7. Yamamoto S, Ito T, Akiyama A, et al. Primary signet-ring cell carcinoma of the urinary bladder inducing renal failure. Int J Urol 2001;8:190-193.

8. Braun EV, Ali M, Fayemi AO, et al. Primary signet ring cell carcinoma of the urinary bladder: review of the literature and report of a case. Cancer 1981;47: 1430-1435.

9. Choi H, Lamb S, Pintar K, et al. Primary signet ring cell carcinoma of the urinary bladder. Cancer 1984;53: 19851990.

10. Bernstein SA, Reuter VE, Carrol PR, et al. Primary signet ring cell carcinoma of the urinary bladder. Urology 1988;47: 1430-1435.

11. Fiter L, Gimeno F, Martin L, et al. Signet-ring cell adenocarcinoma of bladder. Urology 1993;41: 30-33.

12. Ota T, Shimazui T, Hinotsu S, et al. Primary signet ring cell carcinoma of the bladder effectively treated with intraarterial chemotherapy and radiation therapy: a case report. Nishinihon J Urol 1995;57: 1019-1023.

13. Tanaka T, Kanai N, Sugie S, et al. Primary signet-ring cell carcinoma of the urinary bladder. Pathol Res Pract 1987;182:130-35.

14. Krichen Makni S, Ellouz S, Khabir A, et al. Primary signet ring cell carcinoma of urinary bladder. A case report. Cancer Radiother 2005;9(5):322-4. 